Gerontology 1978;24(supp 1):I-VI

\title{
Contents, Supplement 1, 1978
}

Ermini,M. (Zurich): Is There a Biological Basis for Geriatric Pharmacotherapy? .... 1

Boismare, F.; Poncin, M., Le, and Lefrançois, J. (Rouen): Biochemical and Behavioural Effects of Hypoxic Hypoxia in Rats: Study of the Protection Afforded by Ergot Alkaloids

6

Gygax, P.; Wiernsperger, N.; Meier-Ruge, W., and Baumann, T. (Basel): Effect of Papaverine and Dihydroergotoxine Mesylate on Cerebral MicroПow, EEG, and pO, in Oligemic Hypotension 14

Carruthers-Jones, D.I.; Depoortere, H., and Loew, DM. (Basel): Changes in the Rat Electrocorticogram following Administration of Two Dihydrogenated Ergot Derivatives 23

Cahn, J. and Borzeix, M.G. (Montrouge): Comparative Effects of Dihydroergotoxine (DHET) on CBF and Metabolism Changes Produced by Experimental Cerebral Edema, Hypoxia and Hypertension 34

Samorajski, T.; Strong, J.R.; Sun, G.Y.; Sun, A.Y., and Seamen, R. (Houston, Tex.): Dihydroergotoxine and Ethanol: Physiological and Neurochemical Variables in Male Mice 43

Kessler, M.; Höper, J., and Ji, S. (Dortmund): Action of Norepinephrine on Microcirculation and P02 Distribution in the Isolated Perfused Rat Liver 55

Nandy, K. and Schneider, F.H. (Bedford, Mass.): Effects of Dihydroergotoxine Mesylate on Aging Neurons in vitro 66

Gähwüer, B.H. (Basel): Dihydroergotoxine-Induced Modulation of Spontaneous Activi ty of Cultured Rat Purkinje Cells 71

Goldstein, M.; Lew, J.Y.; Hata, F., and Lieberman, A. (New York, N.Y.): Binding Interactions of Ergot Alkaloids with Monoaminergic Receptors in the Brain ... $\eta(\mathrm{i}$ Schorderet, M. (Geneva): Dopamine-Mimetic Activity of Ergot Derivatives, as Mea sured by the Production of Cyclic AMP in Isolated Retinae of the Rabbit 86 Markstein, R. and Wagner, H. (Basel): Effect of Dihydroergotoxine on Cyclic-AMPGenerating Systems in Rat Cerebral Cortex Slices 94

Spano, P.F. and Trabucchi, M. (Milano): Interaction of Ergot Alkaloids with Dopaminergic Receptors in the Rat Striatum and Nucleus Accumbens 106

Enz, A.; Iwangoff, P., and Chappuis, A. (Basel): The Influence of Dihydroergotoxine Mesylate on the Low-Km Phosphodiesterase of Cat and Rat Brain in vitro .... 115

Contents

VI

Iwangoff, P.; Enz, A., and Meier-Ruge, W. (Basel): Incorporation, after Single and Repeated Application of Radioactive Labelled DH-Ergot Alkaloids in Different Organs of the Cat, with Special Reference to the Brain 126

Boulu, R.G. (Paris): Effect of Dihydroergotoxine on Thalamic- and Pyramidal-Evoked Responses in the Cat under Transient Ischemia 
Author Index 150

Subject Index 151 